Absorbing Heinrich Isaac

Author(s): David J. Burn, Blake Wilson, Giovanni Zanovello

Source: The Journal of Musicology, Vol. 28, No. 1 (Winter 2011), pp. 1-8

Published by: University of California Press

Stable URL: http://www.jstor.org/stable/10.1525/jm.2011.28.1.1

Accessed: 04/05/2011 02:37

Your use of the JSTOR archive indicates your acceptance of JSTOR's Terms and Conditions of Use, available at http://www.jstor.org/page/info/about/policies/terms.jsp. JSTOR's Terms and Conditions of Use provides, in part, that unless you have obtained prior permission, you may not download an entire issue of a journal or multiple copies of articles, and you may use content in the JSTOR archive only for your personal, non-commercial use.

Please contact the publisher regarding any further use of this work. Publisher contact information may be obtained at http://www.jstor.org/action/showPublisher?publisherCode=ucal.

Each copy of any part of a JSTOR transmission must contain the same copyright notice that appears on the screen or printed page of such transmission.

JSTOR is a not-for-profit service that helps scholars, researchers, and students discover, use, and build upon a wide range of content in a trusted digital archive. We use information technology and tools to increase productivity and facilitate new forms of scholarship. For more information about JSTOR, please contact support@jstor.org. 


\title{
Absorbing Heinrich Isaac
}

\author{
DAVID J. BURN, BLAKE WILSON, \\ AND GIOVANNI ZANOVELLO
}

\section{$\mathrm{H}$}

inrich Isaac has long been acknowledged as a central figure in late-fifteenth- and early-sixteenth-century music. ${ }^{1}$ His particular importance, especially in German-speaking countries, was already evident in the early nineteenth century: in 1801 Johann Nikolaus Forkel tied Isaac to an explicitly patriotic agenda in the second volume of his Allgemeine Geschichte der Musik. ${ }^{2}$ Shortly after, Ernst Ludwig Gerber first drew critical attention to Isaac's song Innsbruck ich muss dich lassen, thus launching a remarkable career for that piece that continues to this day and assures Isaac a place in not only scholarship but also the broader consciousness, at least of those raised in Germanspeaking countries. ${ }^{3}$ In the later nineteenth century and the early twentieth, the inclusion of a good deal of his music in three volumes of the Denkmäler der Tonkunst in Österreich established Isaac's output definitively as one of the "monuments" of his time. 4

1 See the survey of Isaac reception since the eighteenth century in Martin Staehelin, Die Messen Heinrich Isaacs, 3 vols. (Bern: P. Haupt, 1977), 1: 1-16; and David J. Burn, "The Mass-Proper Cycles of Henricus Isaac: Genesis, Transmission, and Authenticity," 2 vols. (PhD diss., Oxford University, 2002), 1:12-34.

2 Johann Nikolaus Forkel, Allgemeine Geschichte der Musik, vol. 2 (Leipzig: Schwickert, 1801), esp. 518, 669, and 676. See also Andrea Lindmayr-Brandl, "Innsbruck, ich muß dich lassen': Eine Rezeptionsgeschichte des Isaakschen Liedsatzes,” in Heinrich Isaac und Paul Hofhaimer im Umfeld von Kaiser Maximilian I, ed. Walter Salmen (Innsbruck: Edition Helbling, 1997), 255-79, esp. 257-63.

3 Ernst Ludwig Gerber, Neues historisch-biographisches Lexikon der Tonkünstler, 4 vols. (Leipzig: Kühnel, 1812-14), 2: cols. 814-15. See also Walter Salmen, "'Innsbruck, ich muß dich lassen': Die Wandlungen einer popularen Hofweise vom 16. zum 20. Jahrhundert," in Heinrich Isaac und Paul Hofhaimer, 245-53; Kurt Drexel, "'Innsbruck, ich muss dich lassen': Zur nationalsozialistischen Rezeption des 'Innsbruckliedes,'” in Heinrich Isaac und Paul Hofhaimer, 281-86.

4 Heinrich Isaac, Choralis Constantinus, Erster Theil: Graduale in mehrstimmiger Bearbeitung (a-capella), ed. Emil Bezecny and Walter Rabl, Denkmäler der Tonkunst in Österreich 10 (Vienna: Artaria, 1898); Heinrich Isaac, Weltliche Werke, ed. Johannes Wolf, Denkmäler

The Journal of Musicology, Vol. 28, Issue 1, pp. 1-8, ISSN 0277-9269, electronic ISSN $1533-8347$. (C) 2011 by the Regents of the University of California. All rights reserved. Please direct all requests for permission to photocopy or reproduce article content through the University of California Press's Rights and Permissions website, http://www.ucpressjournals.com/reprintInfo.asp. DOI: 10.1525/ jm.2011.28.1.1. 
This firm place in early musicological scholarship has guaranteed Isaac at least a passing mention in even the most standard music history surveys. Yet despite such general acknowledgment of Isaac's accomplishments, he has proven to be uniquely resistant among his contemporaries to mainstream historiographical absorption. This is particularly evident in Anglo-American musicology, where detailed studies of the composer have until recently remained highly sporadic. ${ }^{5}$ In Germanspeaking countries, the nineteenth-century inheritance and his obvious national significance have ensured that he has fared better, though a tailing-off in interest has been evident in recent decades. ${ }^{6}$ An explanation for this peculiar state of affairs in which Isaac is recognized in name but passed over in detail lies, at least in part, in the fact that little in the composer's highly distinctive profile fits the accepted molds of his time. Both biographically and compositionally, he poses significant challenges to generalizations that have increasingly come to derive their model from Josquin. 7

In biographical terms, at least two curiosities must be mentioned. ${ }^{8}$ First, Isaac remained a layman and was married, thus giving up the opportunity to receive the ecclesiastical benefices that secured the living of almost every top-notch singer and composer of his time. Instead of leaving

der Tonkunst in Österreich 28 (Vienna: Artaria, 1907); Nachtrag zu den weltlichen Werken von Heinrich Isaac, ed. Johannes Wolf, Denkmäler der Tonkunst in Österreich 32 (Vienna: Artaria, 1909); Heinrich Isaac, Choralis Constantinus, Zweiter Theil: Graduale in mehrstimmiger Bearbeitung (a-capella), ed. Anton Webern, Denkmäler der Tonkunst in Österreich 32 (Vienna: Artaria, 1909).

5 Three theses are exceptions: Louise Cuyler, "The Choralis Constantinus III of Heinrich Isaac (c. 1445-1517)" (PhD diss., University of Rochester, 1948); William Peter Mahrt, "The Missae ad organum of Heinrich Isaac" (PhD diss., Stanford University, 1969); James David Feiszli, "Performance Editions from Heinrich Isaac's Choralis Constantinus" (D.M.A. diss., Arizona State University, 1983); also highly important are the archival discoveries presented in Frank A. D'Accone, "The Singers of San Giovanni in the Fifteenth Century," Journal of the American Musicological Society 14 (1961): $307-58$, and D'Accone, "Heinrich Isaac in Florence: New and Unpublished Documents," Musical Quarterly 49 (1963): 464-83.

${ }^{6}$ Significant studies include Paul Blaschke, "Der Choral in Heinrich Isaaks Choralis Constantinus: Ein Beitrag zur Geschichte der Cantus Firmus-Technik" (PhD diss., Breslau, 1926); Werner Heinz, "Isaacs und Senfls Propriums-Kompositionen in Handschriften der Bayerischen Staatsbibliokthek München" (PhD diss., Berlin, 1952); Gerhard-Rudolf Pätzig, "Liturgische Grundlagen und handschriftliche Überlieferung von Heinrich Isaacs 'Choralis Constantinus,"” 2 vols. (PhD diss., Tübingen, 1956); Martin Just, "'Studien zu Heinrich Isaacs Motetten," 2 vols. (PhD diss., Tübingen, 1960); and Staehelin, Die Messen.

7 See Paula Higgins, "The Apotheosis of Josquin des Prez and Other Mythologies of Musical Genius," Journal of the American Musicological Society 57 (2004): 443-510.

8 On Isaac's biography, see Reinhard Strohm and Emma Clare Kempson, "Isaac, Henricus," in The New Grove Dictionary of Music and Musicians, ed. Stanley Sadie and John Tyrell (London: Oxford University Press, 2001), 12:576-77. For new biographical information that has been discovered since then, see Blake Wilson, "Heinrich Isaac among the Florentines," Journal of Musicology 23 (2006): 97-152; and Giovanni Zanovello, "Master Arigo Ysach, Our Brother': New Light on Isaac in Florence, 1502-1 7," Journal of Musicology 25 (2008): $287-317$. 
his native Flanders just long enough to secure glory and economic security for himself before returning home, he put down roots in Italy. Isaac clearly benefited professionally from his association with Florence and the Medici network. One can only speculate whether his ability to function in that environment-so preoccupied with propaganda-taught him to interact in special ways with the patronage networks that served him well until his last years. Whatever the case, his decisions both to remain a layman and to settle permanently in Italy had consequences that may have extended to influencing the music that he produced. Had Isaac never returned to Italy from his appointment at the court of Emperor Maximilian I, for example, it would be difficult to imagine works like La mi la sol la sol la mi, perhaps the most radical composition on a soggetto cavato, or the Mass Misericordias domini, in which the Flemish master so remarkably embraces the sound of the Italian lauda. 9

Second, his appointment-as the first professionally employed composer-at the court of Emperor Maximilian I is guaranteed to bring him scholarly attention. Only recently, however, have scholars begun to explore the meaning of this professional obligation to produce musical works and its implications for understanding his historical and musical significance. $^{10}$ Isaac also contributed to developing a new professional profile for musicians, in which composing played an unprecedented part, as numerous contemporary reports attest: his position with Maximilian appears to have allowed him considerable flexibility, and he could thus continue largely to reside in Italy. Among the most famous of those reports today is that sent by agent and singer Gian d'Artiganova to Ercole d'Este in 1502 , in which Isaac is compared to Josquin. ${ }^{11}$ Praise of his compositional skills is also found in several other sources, including a letter from Lorenzo de'Medici to the Venetian ambassador in Rome that singles out the variety of his compositional styles for particular mention. ${ }^{12}$

What the Florentine de facto ruler viewed as a positive characteristic, however, is especially problematic from today's perspective, which often

9 See especially Giovanni Zanovello, "Heinrich Isaac, the Mass Misericordias Domini, and Music in Late-Fifteenth-Century Florence" (PhD diss., Princeton, 2005); and idem, "'Master Arigo Ysach, Our Brother."”

10 Rob C. Wegman, "From Maker to Composer: Improvisation and Musical Authorship in the Low Countries, 1450-150o," Journal of the American Musicological Society 49 (1996): 409-79, esp. 461-69; and Wegman's contribution to the present journal issue.

11 The letter is frequently cited, often to Isaac's detriment; for the text, see Staehelin, Die Messen, 2:56-57. English translations are published in Lewis Lockwood, "Josquin at Ferrara: New Documents and Letters," in Josquin Desprez: Proceedings of the International Josquin Festival-Conference, ed. Edward E. Lowinsky (Oxford: Oxford University Press, 1976), 103-37, esp.132-33; and Wegman, "From Maker to Composer," esp. 466.

12 See Bonnie J. Blackburn, "Lorenzo De' Medici, a Lost Isaac Manuscript, and the Venetian Ambassador," in Musica Franca: Essays in Honor of Frank A. D'Accone, ed. Irene Alm, Alyson McLamore, and Colleen Reardon (Stuyvesant, NY: Pendragon Press, 1996), 19-44. 
seeks to identify an individual and consistent composer's voice behind the surviving repertoire. Isaac has few peers in the history of music for uniting quality with a remarkable eclecticism-in this respect, one could even say that he embodies some of the most important art musical developments of his time. A superbly gifted musician and a curious man, he was able to absorb musical styles and compositional techniques from every region he visited and combine them in original ways. Recent findings, such as the discovery of new documents concerning the song La battaglia that substantiate Isaac's previously questioned role in the refinement of the Florentine Carnival song and-yet more spectacularlyMartin Staehelin and Eckhard Neubauer's claim that Isaac's Allahoy was inspired by a Turkish call to prayer, have only served to consolidate this unique profile. ${ }^{13}$ These examples could be easily multiplied.

An immediate consequence of Isaac's compositional professionalization is readily apparent from a glance at his work list: it is no coincidence that more works survive today from Isaac than from any of his contemporaries. ${ }^{14}$ This staggeringly large surviving oeuvre poses other problems for modern scholarship. Isaac's most historically significant work has long been considered his Mass Propers and German songs, though both genres, when viewed against wider Renaissance music-historical culture and trends, are customarily seen as of only peripheral importance. ${ }^{15}$ In Isaac's case, the situation is exaggerated by the posthumous reception of his Mass Propers in the sixteenth century itself, introducing the potentially troubling charge of conservatism early in his reception history.

In the last decade, a vigorous and renewed scholarly interest in Isaac has been sparked, at least in part, by precisely these challenges and by the opportunities that Isaac offers for enriching our broader knowledge of Renaissance music. In that time, a reevaluation of the musician, his work, and the context in which he operated has sought to reinstate him at the foreground of Renaissance (and sometimes general) musicological studies. Earlier studies naturally provided a solid foundation on which to build. Indeed, the situation is enviably good: an exemplary study presenting all then-known primary documentation concerning the composer has been available since the late $1970 \mathrm{Os},{ }^{16}$

13 Blake Wilson, "Isaac among the Florentines"; and Martin Staehelin and Eckhard Neubauer, "Türkische Derwischmusik bei Heinrich Isaac," in Von Isaac bis Bach: Festschrift Martin Just, ed. Frank Heidelberger, Wolfgang Osthoff, and Reinhard Wiesend (Kassel: Bärenreiter, 1991), 27-39.

${ }^{14}$ Lists of Isaac's works can be found in Strohm and Kempson, "Isaac, Henricus," 584-88, and in Martin Picker, Henricus Isaac: A Guide to Research (New York: Garland, 1991), 19-13o. Both lists need to be updated with recently recovered works.

15 Further discussed in Burn, "The Mass-Propers of Henricus Isaac," 1:30-31; see also Heinrich Isaac and Polyphony for the Proper of the Mass in the Late Middle Ages and Renaissance, ed. David J. Burn and Stefan Gasch (Turnhout: Brepols, forthcoming), introduction.

${ }^{6}$ Staehelin, Die Messen. 
and an up-to-date summary of Isaac's life, work-list, and bibliography of secondary literature was published in 1991.17 A significant amount of the music is available in sometimes excellent and otherwise usually acceptable editions. ${ }^{18}$ The raw materials were thus present for a small rebirth in Isaac studies since the late 199os. With similar efforts underway for some of his more important contemporaries-notably Jacob Obrecht and Alexander Agricola-a double-edged reassessment of the music of the increasingly inappropriately named "Josquin generation" is well along. This reassessment simultaneously places Josquin back on the level with his contemporaries and strives toward a fairer appreciation of those contemporaries. ${ }^{19}$ As this reevaluation continues, as it surely will, a more balanced picture of the complex interactions and dependencies among this outstanding group of composers will likely emerge.

In the case of Isaac, the scope of this reassessment in recent times has been particularly remarkable, as scholars from both Europe and the United States have approached the Flemish composer from a wealth of perspectives in dissertations, articles, book chapters, and thematic collections. New archival documents and the recontextualization of known ones have better defined the details of his whereabouts, his associations, and the contexts of his patronage. ${ }^{20}$ Reassessment of musical sources has shed new light on the transmission of his music. ${ }^{21}$ Individual works and Isaac's production within particular genres have again captured

17 Picker, Henricus Isaac.

18 Notably Heinrich Isaac, Messen, ed. Martin Staehelin, Musikalische Denkmäler 7-8 (Mainz: B. Schott's Söhne, 1970-73); Heinrich Isaac, Opera omnia, ed. Edward E. Lerner, Corpus mensurabilis musicae $6_{5}$ (Stuttgart: American Institute of Musicology, 1974-), still awaiting completion; Heinrich Isaac, Choralis Constantinus Book III: Transcribed from the Formschneider First Edition, ed. Louise Cuyler (Ann Arbor: University of Michigan Press, 1950); and the editions cited in n. 4 .

19 Rob C. Wegman, Born for the Muses: The Life and Masses of Jacob Obrecht (Oxford: Clarendon Press, 1994); Alexander Agricola: Musik zwischen Vokalität und Instrumentalismus, ed. Nicole Schwindt, Trossinger Jahrbuch für Renaissancemusik 6 (Kassel: Bärenreiter, 2006).

${ }^{20}$ Jürgen Heidrich, "Heinrich Isaac in Torgau?" in Heinrich Isaac und Paul Hofhaimer, 155-68; Wilson, "Heinrich Isaac among the Florentines," and idem, "Isaac the Teacher: Pedagogy and Literacy in Florence, ca. 1488," in Music Education in the Middle Ages and Renaissance, ed. Russell E. Murray, Susan Forscher Weiss, and Cynthia J. Cyrus (Bloomington: Indiana University Press, 2010), 287-302; Zanovello, "Master Arigo Ysach, Our Brother'"; idem, "Heinrich Isaac, die Medici und andere Florentiner," in Heinrich Isaac, ed. Ulrich Tadday, Musik-Konzepte 148/149 (Munich: Edition Text + Kritik, 2010), 5-19.

${ }^{21}$ Jürgen Heidrich, Die deutschen Chorbücher aus der Hofkapelle Friedrichs des Weisen: Ein Beitrag zur mitteldeutschen geistlichen Musikpraxis um 1500 (Baden-Baden: V. Koerner, 1993); David J. Burn, "What Did Isaac Write for Constance?" Journal of Musicology 20 (2003): 45-72; Birgit Lodes, "Ludwig Senfl and the Munich Choirbooks: The Emperor's or the Duke's?" in Die Münchner Hofkapelle des I 6. Jahrhunderts im europäischen Kontext: Bericht über das internationale Symposion der Musikhistorischen Kommission der Bayerischen Akademie der Wissenschaften in Verbindung mit der Gesellschaft für Bayerische Musikgeschichte, München, 2.-4. August 2004, ed. Theodor Göllner and Bernhold Schmid with Severin Putz (Munich: Verlag der Bayerische Akademie der Wissenschaften, 2006), 224-33. 
attention and have been investigated from perspectives ranging from philology to various interpretive endeavors. The motets, ${ }^{22}$ the Mass Ordinaries, ${ }^{23}$ the Mass Propers, ${ }^{24}$ and the songs and secular music ${ }^{25}$ have been the objects of more or less detailed recent study. Technical studies of his compositional strategies have attempted to refine our understanding of the means and processes by which Isaac put his pieces together-and by implication, how Isaac compares and contrasts in this respect with his contemporaries. ${ }^{26}$ The composer's reception, whether by the generation that followed, by others later in the sixteenth century, or in later times, has lent fresh insight into his place within the larger historical picture. ${ }^{27}$

22 Emma Kempson, "The Motets of Heinrich Isaac (c. 1450-1517): Transmission, Structure, and Function” (PhD diss., King's College London, 1998); David J. Rothenberg, "Angels, Archangels, and a Woman in Distress: The Meaning of Heinrich Isaac's Angeli, archangeli," Journal of Musicology 21 (2004): 514-78; Thomas Schmidt-Beste, "Stil und Struktur in den Tenormotetten Heinrich Isaacs," in Heinrich Isaac, 65-88; Blake Wilson, "Poliziano and the Language of Lament from Isaac to Layolle," in Sleuthing the Muse: Essays in Honor of William F. Prizer, ed. Kristine K. Forney and Jeremy L. Smith (Hillsdale, NY: Pendragon Press, forthcoming).

23 Adam Knight Gilbert, "Elaboration in Heinrich Isaac's Three-Voice Mass Sections and Untexted Compositions" (PhD diss., Case Western Reserve University, 2003); Zanovello, "Heinrich Isaac, the Mass Misericordias Domini, and Music in Late-FifteenthCentury Florence"; Jürgen Heidrich, "Heinrich Isaacs (?) 'Missa carminum': Überlieferung, Werkgestalt, Gattungskontext," in Jahrbuch der Ständigen Konferenz Mitteldeutsche Barockmusik (2001): 123-39; David J. Burn, "Heinrich Isaac's Missae de Beata Maria Virgine in Context," Die Tonkunst 3 (2009): 27-37; Christiane Wiesenfeldt, "Funktion und Distanz: Heinrich Isaacs Missae de Beata Virgine in ihrem rezeptionshistorischen Kontext," in Heinrich Isaac, $135^{-49}$.

24 Burn, "The Mass-Proper Cycles"; and the essays in Heinrich Isaac and Polyphony for the Proper of the Mass, ed. Burn and Gasch.

25 Martin Picker, "Henricus Isaac and Fortuna desperata," in Antoine Busnoys: Method, Meaning, and Context in Late Medieval Music, ed. Paula Higgins (Oxford: Clarendon Press, 1999), 431-45; Sonja Tröster, "Die Lieder Heinrich Isaacs: In aller Munde und doch ein unbekanntes Repertoire,” in Heinrich Isaac, 20-37; Nils Grosch, “'Es wollt ein Maidlein. . .'. $\mathrm{Zu}$ einem erotischen Lied von Heinrich Isaac," in Heinrich Isaac, 38-46; Markus Grassl, "Grundsätzliches und Spezielles zu Heinrich Isaacs cantus-firmus-gebundenen Chansonarrangements," in Heinrich Isaac, 47-64.

${ }_{26}$ Most important is Jessie Ann Owens, Composers at Work: The Craft of Musical Composition, I450-160o (Oxford: Oxford University Press, 1997), chap. 10, which focuses on another extraordinary circumstance with Isaac: the earliest identifiable autograph of polyphony is from his hand. See also the following essays in Heinrich Isaac: Andreas Pfisterer, "Imitationstechniken bei Isaac"; David J. Burn, "Vom Choral zur Polyphonie: Zu Kompositionstechniken in Isaacs Messproprien"; and Katelijne Schiltz, "Aus einem Hauptgedanken alles Weitere entwickeln!': Die Kanons in Isaacs Choralis Constantinus II.”

27 Stefan Gasch, "'Hic jacet . . . Isaci discipulus . . .': Heinrich Isaac als Lehrer Ludwig Senfls," in Heinrich Isaac, 150-69; Barbara Eichner, "Getting Proper-ly Started: Isaac's Choralis Constantinus and the Introduction of Polyphonic Mass Propers in Southern-German Monasteries," in Heinrich Isaac and Polyphony for the Proper of the Mass, ed. Burn and Gasch; and the essays by Salmen, Lindmayr-Brandl, and Drexel in Heinrich Isaac und Paul Hofhaimer. 
An invigorating stimulus behind this flurry of activity has also been the (re) discovery of new works, most significantly Adam Knight Gilbert's identification of the Missa Je ne fay plus, cited in the correspondence between Pietro Aron and Giovanni Spataro and considered lost, among the anonymous pieces of Munich, Bayerische Staatsbibliothek $3154 ; ;^{28}$ and the addition of a previously entirely unknown Mass, the Missa Presulem ephebeatum, based on a rotulum in honor of St. Martin by Petrus Wilhelmi de Grudencz (a strikingly old model, though Presulem was still popular in Isaac's lifetime) ${ }^{29}$

The articles presented here, fruits of a conference held in $2010,3^{\circ}$ address many of the major themes mentioned above and take significant steps toward absorbing Isaac into wider music-historical discourse. Isaac's status as a pioneer of professional composition and how this might have affected his compositions and their reception is picked up by Rob C. Wegman, building on his earlier work. $3^{1}$ Absorbing Isaac into Renaissance musical history also involves relating his style(s) to that of his predecessors, contemporaries, and successors. In this sense, Alejandro Planchart's sensitive unveiling of Isaac's debt to Regis and Dufay in his sumptuous six-voice motet Virgo prudentissima adds vital new ingredients to understanding the origins of Isaac's style. $3^{2}$ With the exception of Innsbruck, ich muss dich lassen, no other piece of Isaac can claim to have captured the attention of modern performers to the same extent as Virgo prudentissima — to the extent, as Planchart shows, that an established, though incorrect, modern performance tradition has crystallized around it. The sonic experience of the work can now be complemented and enriched through David J. Rothenberg's exposition of the piece's theological and imperial layers. Isaac's influence on the following

${ }_{28}$ Gilbert, "Elaboration in Heinrich Isaac's Three-Voice Mass Sections and Untexted Compositions," 223-41.

29 Heinrich Isaac, Missa Presulem ephebeatum, ed. Martin Horyna, Fontes musicae 1 (Prague: Národní knihovna České republiky, 2002); David J. Burn, "Heinrich Isaac and His Recently Discovered Missa Presulem Ephebeatum," in "Recevez ce mien petit labeur": Studies in Renaissance Music in Honour of Ignace Bossuyt, ed. Mark Delaere and Pieter Bergé (Leuven: Leuven University Press, 20o8), 49-6o.

$3^{\circ}$ The conference, entitled "Heinrich Isaac and His World," took place May 21-23, 2010 at the Jacobs School of Music, Indiana University, Bloomington. For a conference report, see Ruth I. DeFord, "Heinrich Isaac and His World," Early Music 38 (2010): 481-82.

31 Wegman, "From Maker to Composer," 461-69.

$3^{2}$ Along with Pierre de la Rue, the role of Regis as inspiration and model behind Isaac's pioneering of six-voice textures would undoubtedly repay further study, a possibility recently opened up by important new work on Regis himself. See Sean Gallagher, Johannes Regis (Turnhout: Brepols, 2010). On La Rue's importance to the development of six-voice textures, see Honey Meconi, Pierre de la Rue and Musical Life at the HabsburgBurgundian Court (Oxford: Oxford University Press, 2003). La Rue's interest in Isaac's music is witnessed by his Credo setting based on Angeli, archangeli, a connection that has yet to be properly explored. 
generation of composers in German-speaking lands, especially Ludwig Senfl, is well known. 33 But the reception of his music beyond that orbit remains all but unexplored. For that reason, John Bryan's examination of a possible impact in England is thus all the more startling.

In 1954 Walter Gerstenberg finished his review of Louise Cuyler's edition of the third volume of the Choralis Constantinus with the words, "So bleibt wissenschaftlich noch viel zu tun." ${ }_{4}$ Despite the resurgence of interest in Isaac of which the present journal issue is the latest witness, this observation still holds. Among the most pressing issues is the production of a complete critical edition, which is still lacking for Isaac. Plans are now afoot to remedy this, and the background research and source studies that this edition's production entails will certainly generate important new insights into the creation, transmission, and reception of his music. We also need to consider the implications for Isaac from recent studies of his manuscripts; perhaps most notable are those that may shed light on the composer's earliest documented activities, building on Joshua Rifkin's meticulous study of Munich, Bayerische Staatsbibliothek Mus. Ms. 3154 and the recent flurry of scholarly interest in the Segovia Choirbook. ${ }^{35}$ Predicting the future is risky, but whatever it holds, Isaac undoubtedly offers some of the most promising research directions in Renaissance music, and his prospects for the coming years are certainly bright.

Catholic University of Leuven (DB)

Dickinson College (BW)

Indiana University (GZ)

33 Gasch, "'Hic jacet . . . Isaci discipulus. ...."

34 Walter Gerstenberg, review in Die Musikforschung 7 (1954): 119.

35 Joshua Rifkin, "Munich, Milan, and a Marian Motet: Dating Josquin's Ave Maria . . virgo serena," Journal of the American Musicological Society $5^{6}$ (2003): 239-350; and The Segovia Codex: A Manuscript in Transition, ed. Wolfgang Fuhrmann and Christina Urchueguía (Turnhout: Brepols, forthcoming). The hypothesis that Segovia was an important source for Isaac's pre-Florentine music was advanced by Martin Picker, "Isaac in Flanders: The Early Works of Henricus Isaac," in From Ciconia to Sweelinck: Donum Natalicium Willem Elders, ed. Albert Clement and Eric Jas (Amsterdam: Rodopi, 1994), 153-66. 